\title{
.
}

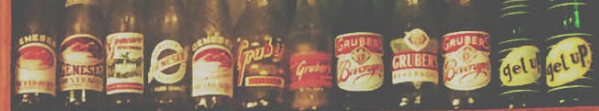
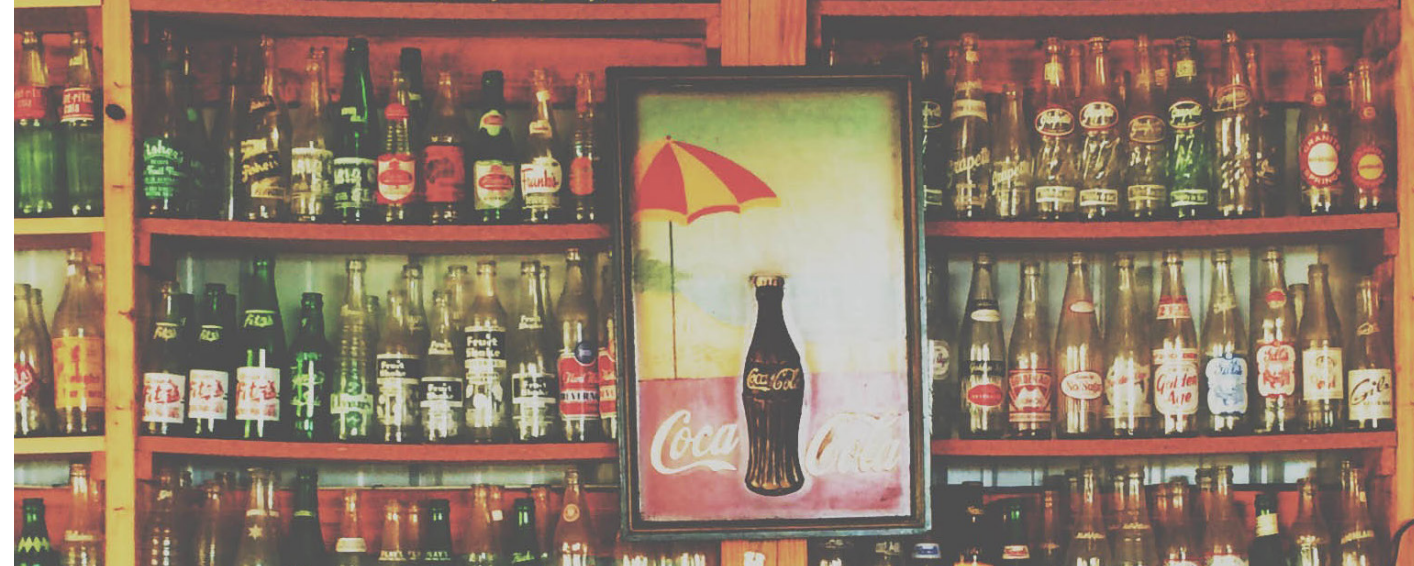

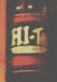

Mintis

in:

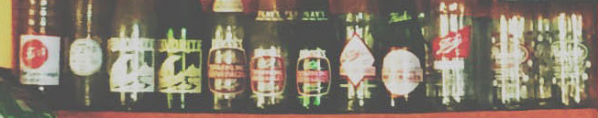

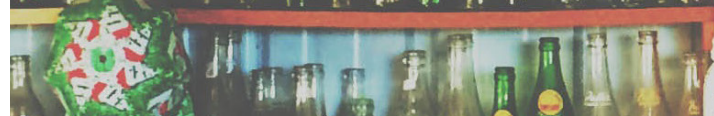

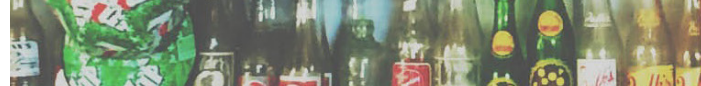

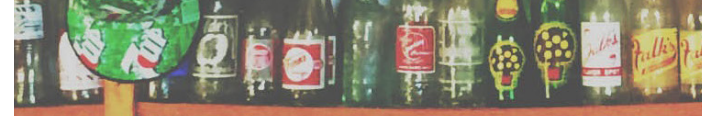
Bireleys $6 \mathrm{a}$ a (1) 1 iी

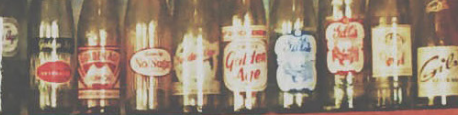

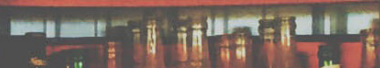

min

8. Cuㅗ. 
Ciberpublicidade. Copa do mundo. Batalha do passinho.

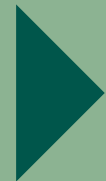




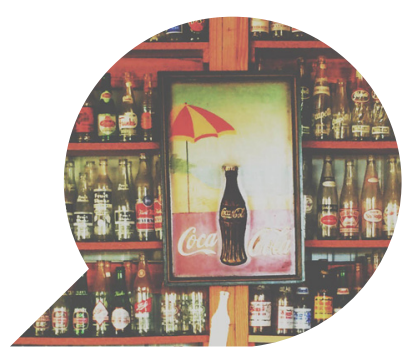

\section{Ciberpublicidade: diferentes táticas de uma narrativa de marca}

\section{Ciberpublicidade: tactics different of a brand narrative \\ Ciberpublicidade: diferentes tácticas narrativas de marca}

\begin{tabular}{c}
\hline MARIANA AYRES TAVARES VASCONCELOS \\
\hline TÂNIA MARIA DE OLIVEIRA ALMEIDA GOUVEIA \\
\hline
\end{tabular}

Resumo: A proposta deste trabalho é analisar dois filmes publicitários, um online veiculado no YouTube e outro off-line veiculado na TV, a partir do conceito de ciberpublicidade, observando os pontos de contato e diferenciação entre eles e de que forma constroem uma narrativa única de marca. Assim, procuramos entender os aspectos da ciberpublicidade, principalmente, a mudança do papel do receptor na construção do posicionamento de marca. Para isso, foram utilizados como estudo de caso dois filmes da Coca-Cola que integraram sua estratégia de comunicação da Copa do Mundo da FIFA 2014. Dessa forma, foi possível observar a ciberpublicidade como um conceito que amplifica os alcances e possibilidades da publicidade tradicional.

Palavras-chave: Ciberpublicidade; Copa do mundo; Batalha do passinho.

\footnotetext{
* Mestranda em Comunicação Social no Programa de Pós-Graduação em Comunicação da Pontifícia Universidade Católica do Rio de Janeiro (PUC RJ). E-mail: ayres.mari@gmail.com

** Doutora em Administração pela Fundação Getúlio Vargas do Rio de Janeiro (FGV RJ). E-mail: almeida.tania@globo.com
} 
Abstract: The purpose of this work is to analyze two advertising films, an online (on YouTube) and other offline (on TV), from the concept of ciberpublicidade to identify the points of contact and differentiating between them and how they build a single brand narrative. Besides this, understand the aspects of ciberpublicidade, mainly, the changing role of the receiver in the construction of the brand positioning. For this, used as a case study of two films of Coca-Cola that integrated the communication strategy of the 2014 FIFA World Cup. Thus, it was possible to observe the ciberpublicidade as a concept that amplifies the scope and possibilities of traditional advertising.

Keywords: Ciberpublicidade; World cup; Batalha do passinho.

Resumen: El propósito de este trabajo es analizar dos películas publicitarias, una emisión online en YouTube y otros TV emitido en offline, desde el concepto de ciberpublicidade mirando los puntos de contacto y distinguir entre ellos y cómo construyen una narrativa única. Así, intentó comprender los aspectos de ciberpublicidade, principalmente, la evolución del papel del receptor en la construcción del posicionamiento de la marca. Para ello, se han utilizado como un estudio de caso de dos películas de Coca-Cola que integra la estrategia de comunicación de la Copa del mundo FIFA 2014. Así, fue posible observar la ciberpublicidade como un concepto que amplía el alcance y posibilidades de la publicidad tradicional.

Palabras clave: Ciberpublicidade; Copa del mundo; Batalha do passinho. 


\section{Introdução}

Atualmente a publicidade tem a internet como mais um componente do media mix, além dos meios tradicionais que ainda possuem grande expressão e recebem a maior parte do investimento direcionado para as campanhas de produtos e serviços. Com a disseminação dos dispositivos digitais, a publicidade encontra novos caminhos para trabalhar seus objetivos de marketing, com diferentes possibilidades de segmentação da mensagem, criação e interação com o consumidor moderno. Este novo modelo vem sendo trabalhado por alguns autores como ciberpublicidade que, em definição seria:

[...] as práticas cotidianas decorrentes do uso generalizado dos diversos dispositivos digitais (normalmente conectados à internet, mas não exclusivamente) forçaram anunciantes e publicitários a reconfigurarem o esquema de abordagem e trato com os consumidores, estabelecendo novas negociações discursivas e constituindo um novo modelo de fazer publicitário, o qual ora classificamos de Ciberpublicidade. (AZEVEDO, 2012, p. 2).

Ao contrário do termo apresentado, aqui trataremos por publicidade tradicional os meios e formatos que são anteriores à reconfiguração causada pelos dispositivos digitais, tais como, filmes para TV, anúncios em revistas e jornais, por exemplo. A escolha dos filmes foi direcionada para dois filmes com aplicações distintas (meios e formatos), mas que fizessem parte do mesmo objetivo de negócio, nesse caso divulgar o patrocínio da marca Coca-Cola à Copa do Mundo da FIFA (Federação Internacional de Futebol), no ano de 2014. Apenas dessa forma isolaríamos as diferenças de objetivos para comparar filmes online e offline e observar os aspectos conceituados pela ciberpublicidade para construção de uma narrativa única de marca.

\section{Referencial Teórico}

A publicidade se divide em diversos formatos e mídias, adaptando sua linguagem e estabelecendo novas conexões e interações com o consumidor moderno, seja em função dos próprios anseios da sociedade de consumo, na qual impera um sistema de capitalismo simbólico, ou da demanda das empresas a partir do objetivo mercadológico. O fato principal para esse estudo está nas nuances da ciberpublicidade e os seus pontos de contato com o formato da publicidade tradicional. 
Além da característica óbvia de estar presente em um dispositivo digital, a ciberpublicidade possui três características importantes: relevância, interatividade e experiência. Essas três características permitem uma troca entre consumidor e marca que agrega novos valores e signos expressos pelo consumidor, para o roteiro de sentido da marca, sendo bom ou ruim. A seguir passaremos por essas três características de forma mais detalhada.

\section{Relevância}

Enquanto na publicidade tradicional o filme acontece na interrupção de uma programação, através do intervalo comercial, no meio digital a relação com o conteúdo publicitário depende de uma ação do usuário, principalmente, quando se trata de conteúdo orgânico. Mas até mesmo no trueview, por exemplo, que é inserido antes de programação escolhida, o usuário tem a ação de ignorar seu conteúdo. A relevância do conteúdo é fundamental uma vez que, para acontecer a interação e o filme/conteúdo ganhar força (views, likes, share), é imprescindível que seja atraente e relevante para o target que uma marca deseja impactar. Para isso, a web tem ferramentas que facilitam a adequação da mensagem ao interesse do target, como por exemplo, seleção de conteúdo que será entregue para o usuário de acordo com o histórico de navegação do mesmo. São várias as ferramentas do meio online que permitem que a publicidade trabalhe de forma segmentada e focada no desejo do consumidor

Para publicidade, ter a estratégia central no consumidor não é uma novidade. Desde o que é chamado por Lipovetsky (2010) de segunda fase do capitalismo moderno, a publicidade deslocou o foco da mensagem do produto para o consumidor. Para o autor, a história do capitalismo moderno se divide em 3 fases, sendo a primeira a publicidade informacional, centrada na descrição do produto, que se estendeu até o final da Segunda Guerra Mundial. A partir da década de 1950 teve início a segunda fase, que tem como principal característica a produção e consumo de massa, já iniciado com o fordismo na primeira fase, mas nesse momento ganhando escala e solidez como modelo econômico.

Com isso, na segunda fase, além de existir mais acesso aos bens de consumo, o fordismo impulsiona o consumo em massa e muda 
a forma de consumir. Essa mudança está refletida nas campanhas publicitárias da época. Enquanto na primeira fase a publicidade é informacional, na segunda fase, com o aumento do mercado competitivo e procura do consumidor, a propaganda tem seu apelo no desejo de consumir. Surgem, então, campanhas que mostram a felicidade através de um estilo de vida particular, de um período marcado pelo desejo de ter e consumir mais do que o próprio produto.

Após a euforia do consumo de lifestyle, a sociedade avança mais uma fase. "Eis chegada a época do hiperconsumo, fase III da mercantilização moderna das necessidades e orquestrada por uma lógica desinstitucionalizada, subjetiva e emocional" (LIPOVETSKY, 2010, p.41). Superando o objetivo de se distinguir do outro, o consumo agora tem como principal objetivo a composição do "eu", deixando de significar a posição social e passando a tratar-se de um consumo emocional e experiencial.

A web tem sua ascensão na fase III do capitalismo de consumo, e surge junto com esta era uma gama de novas possibilidades de conteúdo, mídia, segmentação e métricas. Atualmente, o ambiente digital permite à publicidade segmentar o target por sexo, idade, conteúdo de interesse, conteúdo acessado, por exemplo. Esse complexo de informações permite um plano de mídia mais assertivo e, portanto, um conteúdo mais direcionado, com peças criativas que utilizam linguagem verbal e não verbal mais alinhada com o target e com próprio meio. Outra possibilidade que se abre é a ampliação da capacidade de reação, muito mais ágil e eficaz.

\section{Interatividade}

Nesta fase de crescimento digital, as avaliações constantes da audiência, do conteúdo e da publicidade permitem também uma interação entre marca e consumidor que altera a narrativa tradicional entre eles. Com a publicidade tradicional, o fluxo da mensagem obedecia a um esquema linear entre produção e recepção de mensagem. Esse fluxo foi alterado, principalmente no campo da recepção, no qual o receptor passa a ser também produtor ou coprodutor da mensagem.

Tradicionalmente se afirmava que, na publicidade, o fluxo de comunicação seguia o esquema emissor - mensagem - receptor. Em seus estudos sobre a recepção de mensagem, Hall (2003) defendia 
o esquema: produção - circulação - distribuição/consumo/recepção - reprodução. Ele afirmava que o receptor era a própria fonte para codificação e produção e que a recepção ou consumo/decodificação era influenciado pelo contexto macro, além dos aspectos psicológicos e comportamentais.

Os estudos de Hall são baseados na audiência televisiva, e trouxeram para a publicidade a discussão sobre a produção de sentido estar centrada na recepção e não na produção da mensagem. A ideia é a de que o sentido só se completa no campo da recepção, no qual o consumidor moderno coloca suas visões de mundo e explora as potencialidades dos signos publicitários que são inseridos na produção. E mais, este é um processo dinâmico, no qual a publicidade contribui para os sentidos sociais, reproduzindo ou modificando valores, conceitos e ideias.

Com os dispositivos conectados à internet o processo comunicacional obtém mais uma nuance. O receptor ganha a possibilidade de ser coprodutor da mensagem publicitária, e esta pode ser modificada de acordo com as reações e desejos dessa audiência. Mas, para além dos dispositivos, a mudança real foi comportamental.

Essa transformação cultural pode ser percebida utilizando como exemplo algumas das maiores plataformas digitais que são derivadas de conteúdos participativos, como a Wikipédia, Wikileaks, You Tube, Facebook entre outras. Em todas essas plataformas, principalmente as duas primeiras, os conteúdos são independentes e podem partir também de um indivíduo e não [somente] de uma instituição. Os indivíduos, espontaneamente, participam, interagem e, muitas vezes, criam um conteúdo.

Para a publicidade, esse avanço na participação do consumidor permite que as marcas possam adequar seus conteúdos de forma dinâmica, que o consumidor construa o roteiro de sentido da marca em conjunto com a empresa. A relação entre marca e consumidor final ficou muito mais próxima, desconstruindo de vez a ideia de passividade do público, já iniciada por Hall (2003).

\section{Experiência}

Uma das principais características da ciberpublicidade é a experiência do consumidor com a marca. A alteração no fluxo da mensagem permitiu ao consumidor moderno ampliar os pontos de contato com a marca. 
A experiência é um aspecto variável e se traduz de diversas formas, desde o impacto de um filme de 30 segundos até a participação ativa do consumidor através de um vídeo, por exemplo. Quanto mais estimulado, mais participativos ele pode ser. A experiência é um aspecto que pode aumentar a chance de menções positivas que se multiplicam, e o mesmo pode acontecer com as menções negativas. O consumidor hoje está conectado com o mundo e tem a chance de compartilhar com quantas pessoas for possível a experiência com o produto, serviço ou marca.

A experiência é o pilar que integra os principais pontos de distinção entre a publicidade tradicional e a ciberpublicidade. As mudanças, apesar de possibilitadas pelos dispositivos tecnológicos, são principalmente culturais e comportamentais. A mensagem publicitária e o roteiro de sentido criado pela marca se tornam mais vulneráveis e suscetíveis às mudanças. Ao mesmo tempo em que o feedback constante e a participação do consumidor fortalecem sua relação com a marca, o risco de ocorrer algo negativo também aumenta. A ciberpublicidade torna ainda mais complexa a troca simbólica entre marca e consumidor, fortalecendo características da publicidade como as de operadora e "apropriadora" de aspectos e códigos da sociedade.

\section{Metodologia}

Em relação à metodologia, foi realizado um estudo qualitativo, método que, entre outros aspectos, busca as percepções do consumidor e permite a geração de insights. De acordo com Oliveira (2011, p.103), a pesquisa qualitativa tem o objetivo de "orientar caminhos de comunicação e posicionamento, gerando ideias para melhorias em produtos e marcas", ou ainda "avaliação da mensagem comunicada por comerciais e sua adequação ao público e ao produto veiculado" (OLIVEIRA, 2011, p. 107).

Foi desenvolvido um estudo de caso, que exemplifica os conceitos abordados e, principalmente, levanta o "como" e "porque" (YIN, 2000) dos filmes utilizados na campanha. Para o estudo de caso foi utilizada campanha da Coca-Cola Brasil para Copa do Mundo da FIFA 2014, realizada no Brasil. Esta campanha foi escolhida por ter dois momentos e esforços distintos, online e offline, com objetivos principais diferentes, mas que iam ao encontro da mesma construção de conceito e posicionamento de marca, compartilhando a mesma estratégia. $\mathrm{O}$ 
primeiro momento dessa campanha foi um projeto chamado "Batalha do Passinho" que ocorreu e se disseminou no meio digital. Este projeto foi uma Batalha de Passinho do funk, tipo de dança masculina que mistura passos do funk, frevo e dança de rua, realizada apenas entre os meninos integrantes de comunidades carentes pacificadas no Rio de Janeiro (GOMBATA, 2013). O segundo momento foi a campanha com o media mix da publicidade tradicional, com o tema Copa do Mundo. Essas duas fases da campanha são descritas e analisadas com base na discussão sobre a ciberpublicidade e a publicidade tradicional apresentada na seção anterior.

Para complementar a análise da campanha da "Batalha do Passinho", foi realizada uma entrevista pessoal em profundidade com Michel Gomberg, diretor de marketing regional da Coca-Cola Brasil sobre o projeto. Essa entrevista foi utilizada como fonte para descrição do projeto e validação dos objetivos pretendidos e percebidos através da análise do material.

Na sequência, foram realizados dois minigrupos focais (OLIVEIRA, 2011), tendo de 3 a 5 consumidores cada, seguindo um roteiro previamente estruturado sobre filmes online e off-line da Coca-Cola. Foram pesquisados jovens do Rio de Janeiro, de classe C, não moradores de comunidades carentes.

O minigrupo foi escolhido como estratégia para que fosse possível entender os significados produzidos pela comunicação no campo da recepção. O método foi incorporado ao trabalho, quase assumindo o papel de um "pós-teste" de campanha. De forma aleatória, foram escolhidos para análise os vídeos "Todo Mundo Aperta o Play" (1.260.342 views no You Tube, até 16/09/14) e "Junte Todo Mundo" (280.283 views no You Tube, até 16/09/14). A análise do minigrupo consegue identificar alguns conceitos sociais e culturais que impactam a forma como o indivíduo se relaciona com determinado assunto.

Os resultados foram analisados sob a ótica da semiótica, que é o campo de estudo de todas as linguagens, verbais e não verbais e, por isso, apropriada para as análises dos filmes publicitários. Por definição "a semiótica é a ciência dos signos e dos processos significativos (semiose) na natureza e na cultura” (NÖTH, 2005, p. 17). Ou seja, é a ciência que estuda todos os processos significativos, verbais ou nãoverbais. Para este estudo, foi utilizada a semiótica peirceana, que tem como fundamento o caráter fenomenológico de um signo, se trata de uma teoria pragmática que parte do princípio de que as coisas só 
significam algo desde que produzam um efeito prático no mundo.

O objeto é a coisa em si, como ela é no mundo. O signo é a sua representação. Aquilo que o signo cria na mente de alguém, são os efeitos do signo, chamado de interpretante. Essas relações compõem a teoria triádica do signo, representada num esquema triangular composto por objeto, signo e interpretante. (PEREZ, 2004)

A proposta é entender os filmes como um signo, já que produzem significados, os objetos como os elementos concretos que compõem essa ideia e, o interpretante, o efeito desse signo na recepção. Através da pesquisa qualitativa entende-se o interpretante dinâmico e todas as possibilidades de significado do signo, no caso o filme. Para analisar como esses significados conversam e somam significados para o posicionamento da marca e onde eles divergem ou convergem é necessário o comparativo entre o filme de web e de mídia tradicional.

\section{Estudo de Caso: A Copa do Mundo da Coca-Cola 2014}

Já consolidada nos Estados Unidos, a Coca-Cola começou a ser comercializada no Brasil na década de 1940 e, desde então, expandiu sua atuação. Iniciou suas atividades em Recife (PE), até chegar a todo Brasil. Em 2005, a filial brasileira obteve o melhor desempenho global entre todas as unidades da The Coca-Cola Company, segundo critérios de desempenho de mercado, alinhados às práticas de sustentabilidade. Apenas para destacar a relevância do mercado brasileiro, hoje em dia, o país representa o quarto maior mercado da marca no mundo, consumindo todos os anos mais de 3,8 bilhões de litros da bebida. $\mathrm{O}$ último ranking mundial das 100 marcas mais valiosas divulgado pela consultoria Interbrand tem a Coca-Cola em terceiro lugar, valendo US\$ 81.463 bilhões, atrás apenas da Apple e Google. (COCA-COLA, 2014).

O posicionamento da Coca-Cola é traduzido pelo slogan "Abra a Felicidade", cujo conceito está na linha de comunicação da marca. De acordo com o diretor de marketing regional da Coca-Cola Brasil, Michel Gomberg, entrevistado para a realização deste estudo, a empresa "é muito mais do que um produto, fazemos parte do dia-a-dia das pessoas, temos como orientação apoiar movimentos que promovem uma mudança positiva no mundo. A Coca é sobre otimismo, fazer um mundo melhor" (informação verbal).

Este posicionamento que orienta todas as ações da Coca-Cola encontrou em dois eventos a conexão com sua identidade: A Bata- 
lha do Passinho e Copa do Mundo da FIFA 2014. Os dois eventos aconteceram em momentos distintos, sendo a Batalha do Passinho em 2013 e a Copa do Mundo em 2014, mas possuem a mesma função para públicos diferentes. Suas campanhas trabalham os conceitos de integração e felicidade disseminada pela Coca-Cola. O projeto da Batalha do Passinho, inclusive, já estava incorporado ao conceito da Copa, como integrantes da mesma estratégia de comunicação. Apresentaremos a seguir o que foi cada um desses eventos.

\section{A campanha publicitária da Coca-Cola}

Em junho de 2014, o Brasil sediou a Copa do Mundo da FIFA, o maior campeonato de futebol do mundo. A FIFA categorizou o patrocínio deste evento em três níveis: parceiros da FIFA, patrocinadores da Copa do Mundo da FIFA e apoiadores nacionais, listados em ordem decrescente de relevância. Os "parceiros da FIFA" possuíam maior visibilidade, tendo sido nesta categoria que a Coca-Cola se encaixou.

O filme aqui analisado e exemplo da publicidade tradicional, foi veiculado na TV durante a Copa do Mundo. Estreou na noite anterior ao primeiro jogo da competição. $\mathrm{O}$ filme começa com a lata de refrigerante com o nome "Coca-Cola" em diversas línguas, universalizando o discurso. Em seguida, os cenários e personagens mostram a diversidade de povos, classes e lugares com um elemento, remetendo à celebração. O futebol está, com diferentes códigos, presente em todo o filme.

Outro ponto marcante é a trilha sonora, a música "Todo Mundo", que dizia: Vem que vai começar / Um mundo num só lugar / Cada canto do meu país / Tem sede de ser feliz / E o som da batida / Na palma da mão / E a voz da torcida / É a voz da nação / Eu quero gol Ôô ôô ôôô / Vamos gritar / Ôô ôô ôôôo... É gol, é gol. Vamos espalhar felicidade / É a copa de todo mundo / Vamos juntar o mundo todo / Pra batucar, pra batucar / Juntos vamos fazer / O sonho acontecer / Seja em qualquer lugar / A galera vai cantar (...)

Observa-se que o discurso é democrático ("É a copa de todo mundo") e integrador ("vamos juntar o mundo todo") e o elemento que une a todos é a celebração ("Vamos espalhar felicidade") e ("Eu sou da torcida da felicidade"). Nesse caso, a produção da mensagem, coloca todos os elementos estratégicos e de posicionamento da marca utilizando o tema "Copa". No campo da recepção, tem a influência do 
contexto cultural e situacional (Copa do Mundo da FIFA). Este filme alcançou, também, a reprodução, por meio do apelo multissensorial (visão/audição) da música tema que foi repetida em vários lugares, muitas vezes confundida com a música oficial da Copa do Brasil.

\section{Copa do Mundo e a Batalha do Passinho}

O “passinho" é uma forma específica de dançar o ritmo funk, praticada, em especial, por meninos. Essa dança é um novo ritmo, sendo uma mistura de diversas influências de danças: frevo, dança de rua, entre outras. Surgida nos bailes funks, é disseminada, principalmente, pela internet. Com o "passinho", os dançarinos ganham status por meio de uma tendência comportamental, que alterou as relações sociais estabelecidas nesse ambiente. (GOMBATA, 2013).

Em 2011, nasceu a "Batalha do Passinho", evento criado com o objetivo de disseminar essa forma de dança e apresentá-la para o "asfalto", conferindo-lhe um status artístico e diminuindo o aspecto marginalizado. As batalhas entre dançarinos do "passinho" começaram em 2013 e, ao todo, 16 comunidades participaram do evento. A Coca-Cola foi apoiadora e viabilizou o projeto. Segundo Gomberg:

Aceitar o projeto era corroborar com os valores da Coca, materializando a ideia de que a Coca é muito mais do que um produto, fazemos parte do dia-a-dia das pessoas, temos como orientação apoiar movimentos que promovem uma mudança positiva no mundo.(...) A Coca é sobre otimismo, cultural, fazer um mundo melhor. GOMBERG, Michel. Michel Gomberg: depoimento [fev. 2014]. Entrevistadora: Tavares, Mariana Ayres. Rio de Janeiro.

Este projeto deu origem a outro maior, cuja competição aconteceu pouco antes da Copa do Mundo e, assim como a comunicação do evento esportivo, trazia mensagens referentes à celebração, uma festa, uma dança. Gomberg afirma que: "como resultado, foram mais de 100 mil pessoas impactadas diretamente. Tivemos um retorno de mídia em torno de oito vezes o investimento e a relevância de marca cresceu significativamente" (informação verbal).

O evento gerou um vídeo, veiculado no canal Baile do Passinho no You Tube, com o título "Todo mundo aperta o play", que mostra a dança, os códigos culturais locais e sua conexão com a Coca-Co- 
la. Utiliza-se a cidade do Rio de Janeiro e as pessoas do lugar como pano de fundo para dança. O filme, em setembro de 2014, possuía um pouco mais de 7 milhões de views e, no Facebook, a página dos ganhadores da competição de dança possui mais 160 mil curtidas.

\section{Análise comparativa entre publicidade e ciberpublicidade}

O estudo de caso Coca-Cola auxiliou no entendimento de como a ciberpublicidade se apresenta como um novo fazer publicitário e os momentos em que se distancia da publicidade tradicional a partir dos três eixos apresentados no primeiro capítulo: relevância, interatividade e experiência.

Comparando os dois filmes que são objetos desse trabalho, por ter maior capacidade de segmentação, o veiculado na web "Todo mundo aperta o play” tem o conteúdo (código e linguagem) mais direcionado e, portanto, mais assertivo. Já o filme de 30 segundos, "Junte Todo Mundo", é mais amplo e, por consequência, a mensagem mais dispersa. A temática do passinho já é envolvente e relevante por ser um conceito que, mesmo apropriado pela marca, surgiu a partir de um movimento espontâneo na sociedade. É o global (internet e marca) se apropriando do local (passinho e sociedade), para estabelecer um diálogo com um público-alvo especifico.

De acordo com os consumidores pesquisados, o filme de web, "Todo Mundo Aperta o Play", "é mais voltado para comunidade". Apesar de ser considerado atrativo, parece não dialogar com quem é de fora das comunidades em que a dança é praticada. Fica evidente que, ao mesmo tempo em que o filme é considerado "muito legal", não gera identificação e reconhecimento: "Não tem a ver comigo". Já em relação ao comercial tradicional: "eles puxam mais pelo global e não puxam tanto pelo lado carente".

Sobre a interatividade, é o eixo que mostra maior distanciamento entre o novo e o tradicional modo de fazer comunicação. A internet possibilitou, ao filme "Todo Mundo Aperta o Play", extensão e projeção alcançando espaços para além da comunidade. Os pesquisados apontam um distanciamento que pode ser interpretado como indício de que, se não fosse disseminado via internet e chegasse até o público fora das comunidades esse trabalho não teria atingido o alcance e a repercussão que conseguiu. O compartilhamento, comentários, 
posts e curtidas parecem ter impulsionado o projeto, dando maior visibilidade e trazendo uma característica muito forte de integração. Enquanto isso, a publicidade tradicional alcançou o nível da reprodução no fluxo da mensagem, com a música que conquistou muitos consumidores durante a Copa, se confundindo diversas vezes com a música oficial do evento.

$\mathrm{Na}$ ciberpublicidade, a exemplo do que aconteceu no vídeo “Todo mundo aperta o play", há uma mudança na forma e intensidade de interação com o conteúdo e isso parece ser necessário para que a campanha cumpra seu objetivo.

É interessante notar que a experiência para Batalha do Passinho foi online e off-line. Cada batalha gerava experiência e ampliava relação com o evento e com a marca. O filme "Todo Mundo Aperta o play" conta com a participação de alguns integrantes da competição de dança que são, na verdade, pessoas comuns, que filmaram, fotografaram e aparecem no filme durante essa experiência. A própria interação é uma experiência. Compartilhar com um amigo, curtir e, para além do filme, o projeto como um todo, torcer, acompanhar os resultados das batalhas, as histórias dos participantes, ir aos eventos. O filme tradicional pode gerar experiência sensorial, porém sempre limitada à audição e visão. A música é o ponto de contato mais forte entre os dois filmes da campanha, e pode ter cumprido o papel mais sensorial para o meio offline.

Além de passar pelos eixos destacados da ciberpublicidade e pontuar, principalmente, as diferenças entre os filmes, embasados pelos conceitos da pesquisa qualitativa, é importante entender a linguagem visual e os códigos desses dois comerciais e suas correlações com o posicionamento da Coca-Cola. Para isso, apresentamos a seguir o esquema proposto pela semiótica para entendimento de um signo, a tríade marcaria, considerando nesse caso, os dois filmes como os signos, os objetos são respectivamente, o passinho e a Copa do Mundo, ou seja, aquilo que o signo intenta representar, e por último, como interpretante as primeiras impressões obtidas nos minigrupos sobre cada filme. 
Tríade "Todo Mundo Aperta o Play" (PASSINHO, 2013)

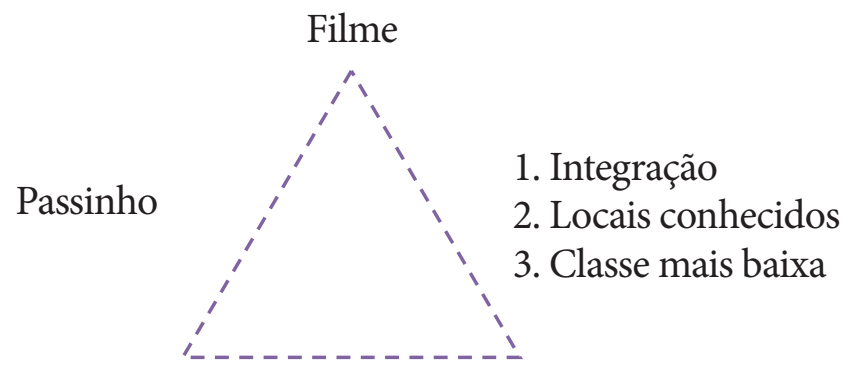

Tríade "Junte Todo Mundo" (COCA-COLA, 2014)

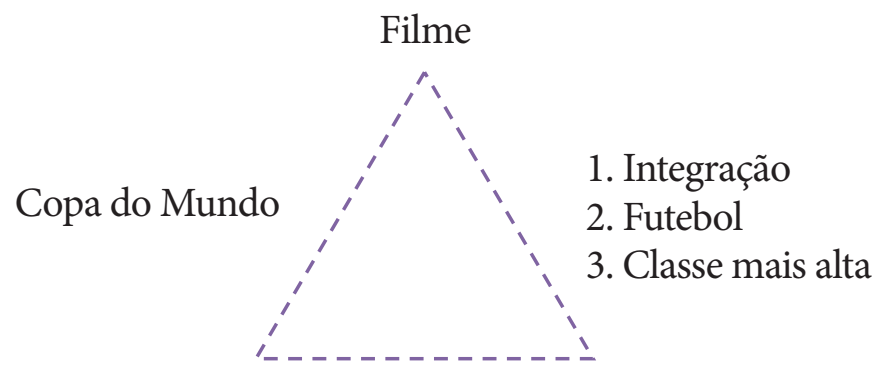

Os filmes (signos) representam objetos diferentes, mas chegam a um mesmo interpretante pelo o que os une, a marca Coca-Cola. O filme "Todo Mundo Aperta o Play" tem um papel fundamental para gerar essa interpretação; a "Batalha do Passinho", usada como parte da estratégia da Coca-Cola para a Copa do Mundo, absorveu o posicionamento de ser celebração e ao mesmo tempo integração, quando apresenta que a marca celebra com qualquer pessoa. E aprofundando um pouco mais, é a Coca-Cola que traz o passinho, que o integra socialmente fora da comunidade. Há, portanto, no campo da recepção, uma troca simbólica na qual a marca e o evento trocam sentidos. A Coca-Cola, por patrocinar o evento, se apropria do caráter social e, para um olhar de fora, vira a marca a responsável por integrar o grupo em outros locais da sociedade.

Os filmes se distanciam, principalmente, pelo entendimento de para quem se destina cada um deles. A percepção geral nos minigrupos é a de que o filme "Todo Mundo Aperta o Play" seria destinado 
a um público de uma classe econômica mais baixa, moradores de comunidades e áreas carentes, por exemplo. Enquanto o filme "Junte Todo Mundo" seria voltado para "classes mais altas", ainda de acordo com os participantes dos minigrupos. Os códigos que aceleram essa interpretação são os espaços urbanos escolhidos como cenário de cada filme e o figurino, pontos definidos na produção da mensagem que são decisivos na percepção do público. Nos minigrupos, quando questionados sobre a possibilidade de o filme da "Batalha do Passinho" ser veiculado na TV aberta, as opiniões foram divididas entre reforçar que a Coca-Cola é para todo mundo e associar a marca às classes sociais mais baixas. Seguem algumas citações dos minigrupos: "Tipo de música, as roupas, os locais e as próprias pessoas", "As pessoas... já é uma outra classe social, as pessoas estão muito bem arrumadas, os ambientes são melhores", e "Se veiculado no meio tradicional traria pontos negativos para marca - por ser um horário nobre".

Tanto no minigrupo, quanto nas etapas anteriores do estudo, ficou claro que a marca conseguiu incorporar à sua estratégia mais algumas características ao seu roteiro de sentido, reforçando a "felicidade" através da celebração e a "brasilidade" pelos cenários e temáticos utilizados. Principalmente, se tornou uma marca "integradora". Em âmbito global, apresenta a Copa como uma competição para todos e reforça os códigos culturais de outros países. E no âmbito local, com a "Batalha do Passinho", tenta romper barreiras entre o "asfalto" e a comunidade. Algumas citações dos minigrupos que transparecem essa ideia: "Fala com o mundo" e "Todo mundo bebe Coca-Cola, eles têm alguma coisa em comum”.

\section{Considerações finais}

Após a análise acima apresentada, fica evidente que mesmo com uma dinâmica diferente, a ciberpublicidade não atua sozinha no meio online para construção de marca, é um "novo fazer” publicitário que não abandona as práticas tradicionais, mas que aproveita a amplitude de oportunidades e ferramentas disponíveis no meio online para, em conjunto com a publicidade tradicional, complementar e reforçar o discurso da marca. No caso da Coca-Cola, a estratégia presente era a mesma nos dois filmes analisados, porém taticamente as campanhas pegaram caminhos distintos. O que constrói a ilha de sentidos de 
uma marca é feito através da construção tática, que permite a marca trabalhar de diferentes formas, dialogando com públicos e linguagens diferentes, porém com um objetivo comum.

A alteração no fluxo da mensagem é um avanço importante e amplia o diálogo entre marca e consumidor. Mas a publicidade tradicional não se torna menos eficaz nem o meio online deve ser visto como mero complemento na tática de campanha. Ao se tornarem coprodutores do roteiro de sentido da marca, esses conteúdos podem servir como "termômetros" do que a comunicação está construindo ou alcançando com o discurso/estratégia adotada. Como por exemplo, as interações com o conteúdo, curtir, compartilhar, comentar, como exposto anteriormente no trabalho, são ações que dependem da motivação do próprio usuário. É como se fosse uma pesquisa constante da comunicação.

Os principais pontos de contato entre as campanhas online e offline são variáveis. Porém, a conexão principal será sempre o conceito (estratégia) da campanha. O desdobramento tático é variável, mas o objetivo estratégico deve sempre ser o mesmo, considerando que os dois filmes fazem parte de um objetivo comum. Os aspectos subjetivos e emocionais do posicionamento de marca e conceito de campanha sustentam a unidade entre os dois filmes.

Portanto, a ciberpublicidade, como um novo fazer publicitário, aumenta o campo de atuação da comunicação e, por consequência, os pontos de contato da marca com o consumidor, permitindo mais possibilidades de atingir o objetivo mercadológico. O ponto de contato entre o tradicional e o novo fazer publicitário é a estratégia, que deve ser pensada em conjunto ou desdobrada a partir de um objetivo comum.

\section{REFERÊNCIAS}

AZEVEDO, S. T. A ciberpublicidade como novo modelo de fazer publicitário: análise da campanha "Quem faz nossa história é você". In: XXXV Congresso Brasileiro de Ciências da Comunicação, 2012, Fortaleza - CE.

BAILE DO PASSINHO. Disponível em: <www.youtube.com.br/bailedopassinho>. Acesso em: 14 Out. 2014.

COCA-COLA. Disponível em: <www.cocacola.com.br $>$. Acesso em: 14 Out. 2014. 
Disponível em $<$ https://www.youtube.com/watch?v=5NJ0COvnF_0>. Acesso em: 14 Out 2014.

GOMBERG, Michel. Michel Gomberg: depoimento [fev. 2014]. Entrevistadora: Tavares, Mariana Ayres. Rio de Janeiro.

GOMBATA, Marsílea. A Batalha do Passinho retrata febre que tomou o Rio. Revista Carta Capital, 2013. Disponível em: $<$ http://www.cartacapital.com. $\mathrm{br} /$ cultura/mergulho-antropologico-a-batalha-do-passinho-retrata-febre -que-tomou-o-rio-1348.html>. Acesso em: 14 Out. 2014.

HALL, Stuart. Codificação/Decodificação. In Da Diáspora: Identidades e mediações culturais. Belo Horizonte: UFMG, 2003.

KOTLER, Philip. Marketing para o Século XXI: como criar, conquistar e dominar mercados. Rio de Janeiro: Ediouro, 2009.

LIPOVETSKY, Gilles. A Felicidade Paradoxal: ensaio sobre a sociedade de hiperconsumo. São Paulo: Companhia das Letras, 2010.

NÖTH, Winfried. Panorama da semiótica: de Platão a Peirce. São Paulo: Annablume, 2005.

OLIVEIRA, Diva. Introdução à pesquisa qualitativa In: PERDIGÃO, Dulce Mantella; HERLINGER, Maximiliano; WHITE, Oriana Monarca (Org.). Teoria e prática da pesquisa aplicada. Rio de janeiro: Elsevier, 2011.

PASSINHO. Disponível em: $<$ https://www.youtube.com/watch?v=rrtFy5C02Pc $>$. Acesso em: 14 Out 2014.

PEREZ, Clotilde. Signos da Marca: Expressividade e Sensorialidade. São Paulo: Pioneira Thomson, 2004.

YIN, Robert k. Estudo de caso: planejamento e métodos; trad. Daniel Grassi - 2.ed. - Porto Alegre : Bookman, 2001

YOUTUBE. Disponível em: <www.youtube.com.br/cocacola $>$. Acesso em: 14 Out. 2014. 


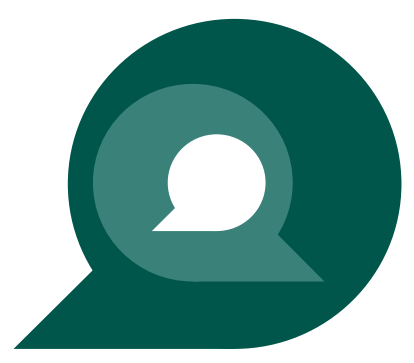

